\title{
A Contingent Agency: Gembel and the Print-Making Project
}

\author{
Angie Bexley ${ }^{1}$ \\ Australian National University, Canberra, Australia
}

\begin{abstract}
Timor-Leste's Independence has offered a new site of expression for "resilient" power relations established during the clandestine movement. However, within this new site, there have been fractures and splinters as Timorese try to stake a claim on power and belonging. Young Timorese involved in the Gembel art collective have managed to forge a new habitus - a space in which they can exercise a degree of agency to reclaim their youth identity through taking part in a crosscultural art project.
\end{abstract}

Keywords: youth, agency, resilience

This article explores power relations between members of the Geracão Foun (Tetum. New Generation) during the 2006 socio-political crisis and the notion of contingent agency in the context of a collaborative cross-cultural art partnership between East Timorese, Australian and Indonesian artists. Agency is seen as the availability for choice and action within a certain time and place (Bourdieu 1977). Building on my PhD fieldwork, conducted between 2005 and 2008, the article has two sections. Section One: Historical Context begins with a discussion of the fractures within the Geracão Foun that emerged as a result of the 2006 social and political crisis and the deepened sense of marginality experienced by the Dili-based art collective Gembel. I offer a new meaning to the emerging discussion of "resilience" in Timor-Leste (Mcwilliam: 2005; Bovensiepen: 2014) whereby enduring power relations established during the clandestine movement have found a new site of expression in the context of Independence. Section Two: Experiences of Contingent Agency discusses a cross-cultural project involving Gembel and the Canberra-based Culture Kitchen art collective and the ways in which this project engaged young East Timorese. In particular, it looks at the ways they forged a new habitus - a space in which they exercised their agency in order to express and reclaim a youth identity embedded within national belonging, outside of the "resilient" power relations in local structures that marginal-

1 Dr Angie Bexley is a Research Associate in Anthropology, School of Culture, History and Language, College of Asia and Pacific. Email: Angie.Bexley@anu.edu.au. The author wishes to thank two anonymous reviewers and the editors for their thoughtful comments. 
ised their voices.

My research over the past decade has focused on the Geracão Foun, sometimes also called the "Generation of "99", as a reference to the role these young people played in the Independence struggle of Timor-Leste from Indonesia in 1999 (see Bexley 2009, 2013). This generation contrasts itself with the Portuguese-speaking "Generation of " 75 " as the core group of elites who now dominate the government are known. Roughly, the "Generation of 99 " includes those born after 1970, but the biological parameters of the group are flexible and membership is defined more by experiences with the clandestine resistance movement than a certain age. During the early years of Independence, this generation maintained a sense of cohesion through the marginality that they experienced in relation to the nation-state as it shifted away from the influence of Indonesian language and culture towards Portugal, which was a world away from these, Indonesian-educated Timorese. By focusing on a group of young East Timorese, my work has explored the creation, maintenance and reproduction of youth identities and the attempts of these youth to belong within the postcolonial nation-state. The driving question in this endeavour has been: what can we learn from their accounts about the new forms of identity that they developed from interstitial positions of power relations?

More than a decade after Independence, it is evident that there is now a younger generation of youth who have come of age in a new era largely defined by the lack of conflict and violence experienced during the occupation. These young people did not experience the Independence struggle on the streets of Indonesia as student activists like the core group of the Geracão Foun. This next generation of Timor youth experienced the occupation as children. They too felt the fear, and at times abandonment associated with the occupation. Importantly, they now experience a continuing sense of marginalisation, all without a sense of entitlement to the heroic symbols of youth, as claimed by the core group of the Geracão Foun. To complicate matters, the younger group identify themselves as members of the Geracão Foun. They speak Indonesian and identify with popular and radical pro-democracy cultures and groups within Indonesia. Their marginalisation is in relation to both the pro-Portuguese language policy and the valorisation of the veterans and the more politically visible sections of the resistance movement.

In this article, I present a case study of the habitus (Bourdieu: 1977) of the art and music group, Gembel to demonstrate something of the complexities and contingent nature of agency in Timor-Leste after the social-political crisis of 2006. Rather than operating in a solely "local" or "traditional" set of power relations, I suggest that their worlds have become enmeshed in international practices of art and therefore, the options available to them are also contingent upon these connections. It is here that they draw upon their "weapons of the weak" (Scott: 1985). Their motivations for action and identities are multifaceted as they draw on a range of gendered, historical and transcultural references in order to assert a sense of agency and meaning. While Gembel members indicate their appeal for a military style of leadership, they simultaneously draw on relationships forged with international artists, concepts of peace and justice, and their villages of origin to make meaning out of their lives on the margins. In short, the habitus in which they operate, and in which agency is available to them, is defined by interconnection, marginality and liminality, rather than by a single lens of conflict or traditional power structures.

The ways in which Independence has provided opportunities to transform power relations is a relatively new field within Timor studies (see Bexley: 2009; Bovensiepen: 2014; NygaardChristensen: 2012:). Rather than affirming that social and political life engender "resilience" 
through the "reproduction of [traditional] East Timorese society", where indigenous "systems" (McWilliam: 2005) are able to remain intact, I suggest that the power relations that were established during the resistance movement have also proved "resilient". The ways in which young people were excluded from the realms of decision-making in the structure of the resistance movement (see Bexley\& Rodrigues: 2013; Bexley \& Nygaard-Christensen: 2014) perpetuated after Independence, and young East Timorese continued to be excluded from decisions made about their nation and themselves.

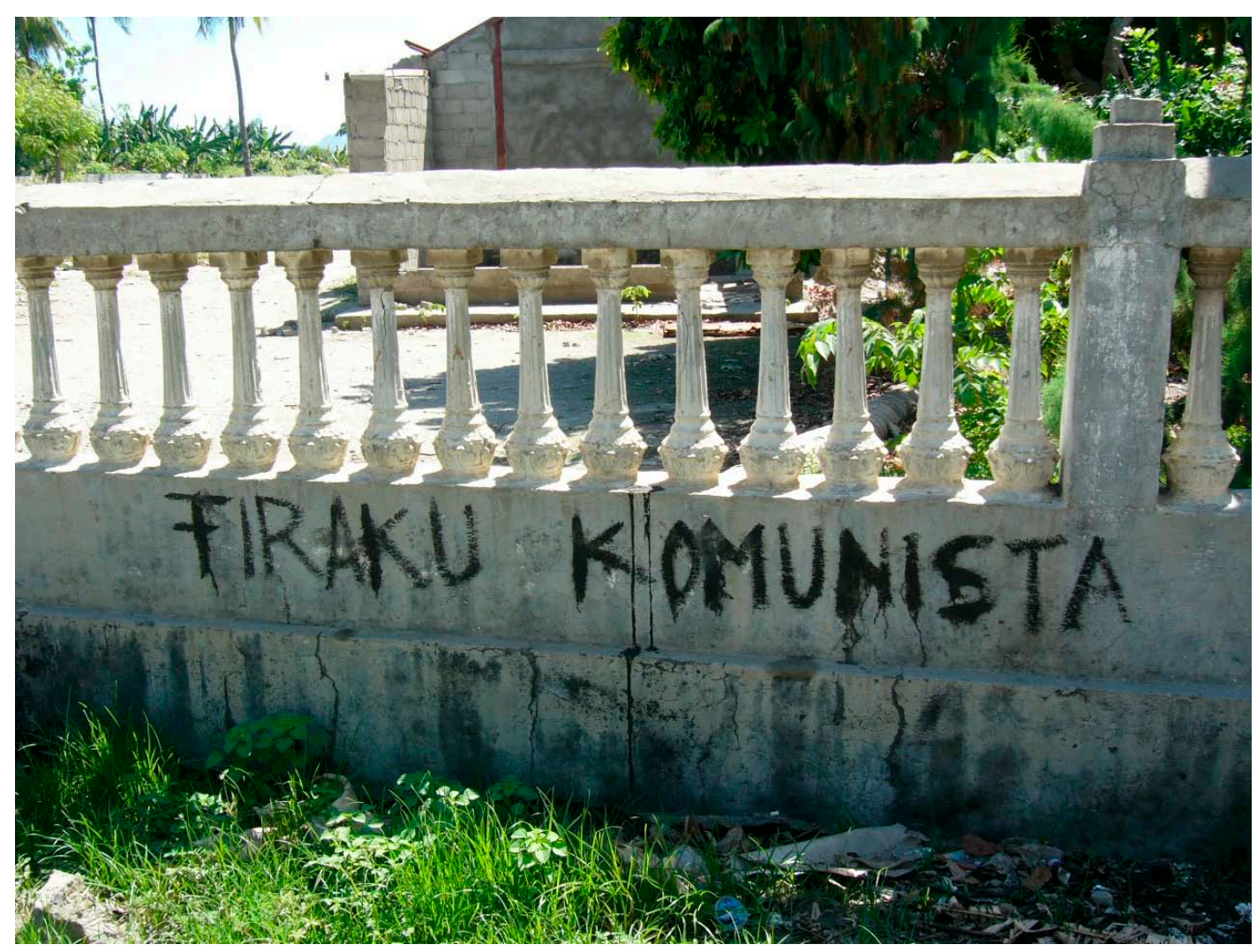

Graffiti painted on a wall in Dili says "Firaku-Komunista”(Easterner's are communists) invoking the spectre of the "communist threat" constructed in Indonesia during Suharto's rule. Photo by author.

\section{Historical Context}

Gembel's choice of name illustrates its sense of marginality and liminality. Gembel is an Indonesian word that means "vagrant" or "vagabond". The members of Gembel articulate a profound sense of liminality that has two elements. They were not quite a part of the resistance movement (and thus cannot claim the "heroic youth status") due to their age. Moreover, they have not been fully integrated into processes of national belonging due to their exclusion by the nation-state as they, like the older members of the Geracão Foun, have closer ties with Indonesia than Portugal. The group took on the derogatory name to describe their theatre, music and printmaking activities. Membership is diverse, age ranges from 15 to 25. Most of the members are male but include some younger females. Most of the females, however, are not full-time and tend to drop out after they have children, as the weight of family responsibilities tends to fall exclusively on women. Some members were finishing high school or attending university 
and others have dropped out and remained unemployed, supported by the collective and family members. They are an unusual youth group in that members come from both the eastern and western districts of Timor and transverse political party membership.

Gembels choice of residence also depicts their marginal position in East Timorese society. In 2005, they occupied the space that was the headquarters of the Dili scouts during Indonesian occupation. The small shelter with three rooms, a bathroom and a makeshift kitchen is within the Borja da Costa Memorial Park in the elite suburb of Farol, which is home to foreign embassies and international organisations and located in the middle of Dili.

Some Gembel members have had children in the last couple of years. When I asked them what their plans are for their children, considering that found it almost impossible to finish their own schooling - let alone to get a job - they shrugged and laughed. "Loron obin ne"e hau moris", I live for today, they say. Their marginality in independent Timor-Leste restricts their capacity to plan beyond the present. Meanwhile, the past, as it is constructed in national discourse, does not belong to them. What matters is the present.

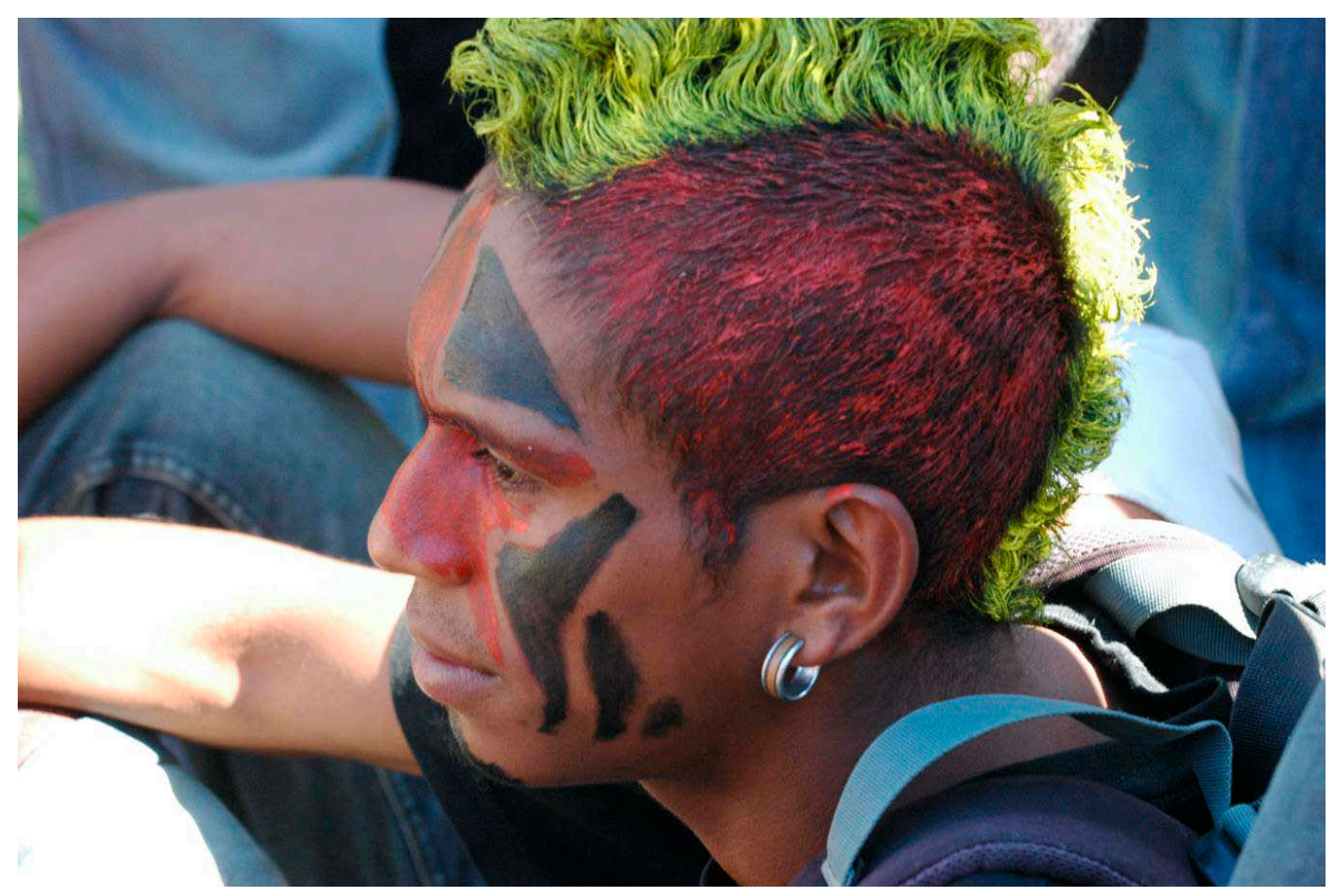

A young protester. Photo by Carlito Caminha.

The divisions that occurred after the 2006 crisis clearly illustrate the limits of agency and the impact of the relentless exercise in defining inclusion and exclusion in the post colonial state. The confusion and chaos of the 2006 crisis entailed the breakdown of the police force, a coup to oust Prime Minister Mari Alkatiri and the burning and looting of hundreds of houses. The key factor for youth during this crisis was the extent that it fostered divisions among those from the east and the west of the country, known in Tetum as Firaku (east) and Kaladi (west). Some of the issues were pre-existing among the different groups and the crisis released years of frustrations. Easterners who showed their support for Mari Alkatiri at the time of the sociopolitical were labelled "communists". 
During the socio-political crisis, some of the older members of the Geracão Foun ridiculed Gembel for being involved in some of the anti-government protests. The older more influential members of the Geracão Foun asserted that participation in the anti-government protests was the wrong kind of protest and that they were in favour of the Fretilin-led government at the time. Gembel members were subsequently ostracised from social activity at the NGO and the wider NGO community and elite suburb of Farol. A certain paradox was evident in the behaviour of the Geracão Foun towards Gembel members. The older members of Geracão Foun were marginalised by the nation-state for their association with Indonesia, where they had studied during the 1990s and become fluent in its languages and cultures. In turn, the older members of the Geracão Foun marginalised the new generation that emerged out of the 2006 crisis, sometimes referred to as post-independent youth, because of the older members' claim on cultural citizenship based on ideas of youthful patriotism and sacrifice. The younger, post-independent youth were stamped as being a "disgrace to youth".

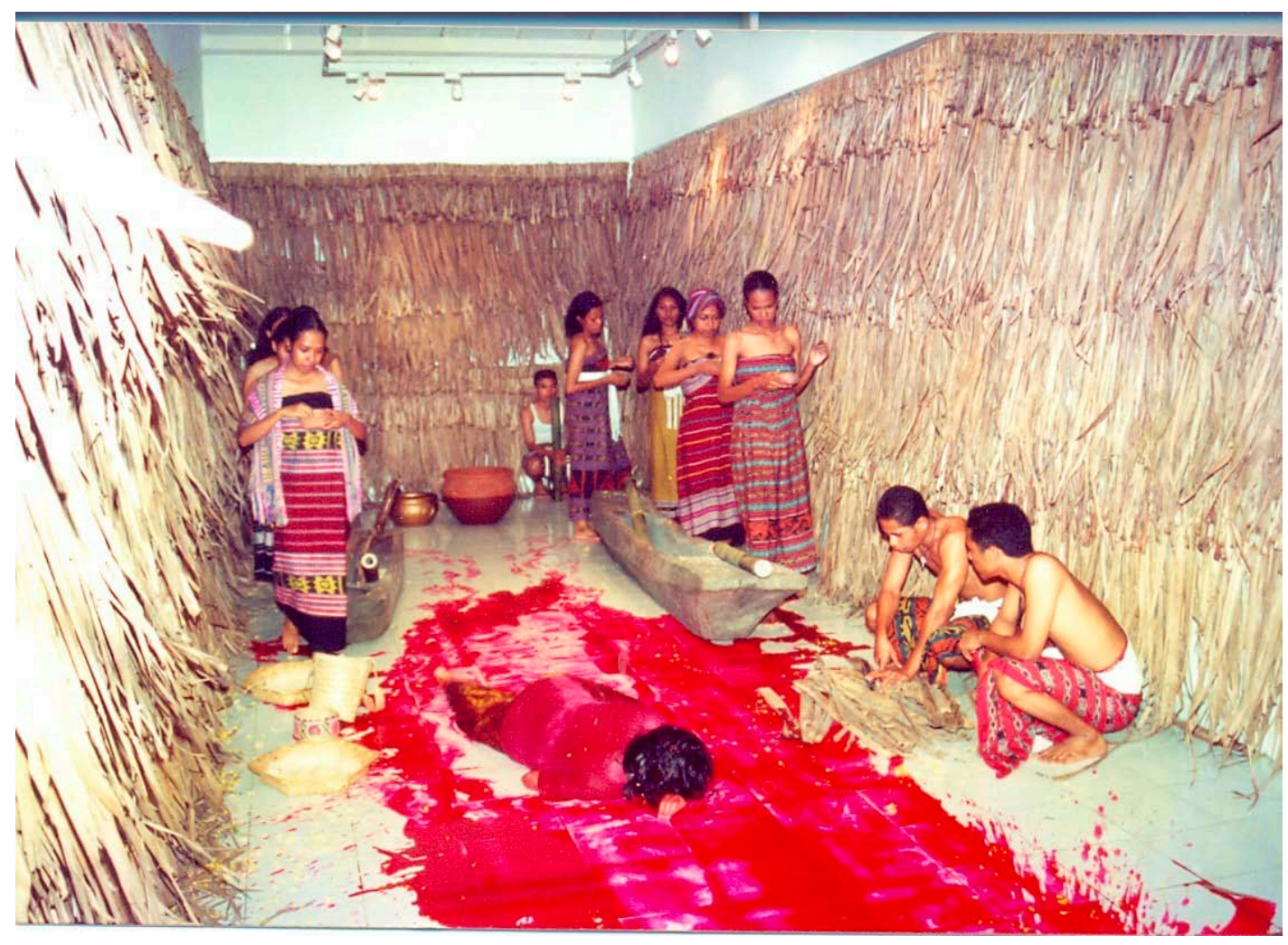

"Geracão Foun" members perform a theatrical protest in Yogyakarta in the 1990s as part of their "Lezaival" theatre group. Photo by Iwan Wijono.

Their status as post-independent youth meant that young East Timorese involved in groups like Gembel always maintained a tenuous membership in the Geracão Foun. This unclear status was based on a number of issues. Both the post-independence and pre-independence youth were fluent in Indonesian, however, they had very different experiences as youth. The post-independence youth were just young children during the occupation. This meant the roles they played as young children did not fit the "heroic" youth narrative of their predecessors who were at the forefront of demonstrations and on the podiums beseeching Timor Leste's independence on the streets in Indonesia. They also had a limited knowledge of the resistance and its structure. What became clear in this time was that a repetitive cycle of defining belonging through marginalisation, from the Portuguese elite and now the older members of the Geracão 
Gembel represents the complexity of youth identity and marginality. When I asked one of the Gembel members, Mahatu, why he participated in the demonstrations, he explained that economic marginality was a major motivating factor. Mahatu recounted how a youth leader (who was aligned to one of the political parties of the time) began paying visits to the group's "headquarters" in the Borja da Costa Memorial Park in the centre of Dili around the end of March, 2006. He asked them to paint a banner for the anti-government protests. When I asked why the group had agreed, Mahatu explained, "If somebody offers you money, you take it." This was reminiscent of responses of those from the older generation when I asked them why they were involved with pro-autonomy leaders such as militia leader Hercules. ${ }^{2}$ The issue of fluidity of association with members of pro-Indonesian groups and militia and mutual gain was also evidenced by the older members of the Geracão Foun and so for them to criticise the younger Timorese for engaging with 'disruptive elements' missing a critical point about young Timorese. This behaviour reveals something of the narrow choices that are available to youth living on the margins of society.

Mahatu and the other members of Gembel were drawn to military and masculine styles of leadership. The predominant style of leadership in Timor-Leste emerged out of the struggle with Indonesian occupation. It articulates a resistance identity forged out of historical and contemporary constellations of power and the experience of marginality, which fostered a culture of secrecy. Among the unambiguous markers of effective resistance and leadership during the resistance were: tenacity; unwavering resoluteness; austerity; an adversarial, disciplined and autocratic style; an hierarchical structure and order of command; and zero tolerance for insubordination. Under the given conditions, displays of a willingness to negotiate and compromise could be viewed as a sign of weakness. While some members of the Geracão Foun began to lose faith in the leadership, particularly in Xanana Gusmão, for post-independent East Timorese, the symbolic value of the idealised military leader remained (see Bexley: 2013).

After the 2006 crisis, popular support for the rebel leader Major Alfredo Reinado ${ }^{3}$ rose among young East Timorese, particularly in Dili. Gembel members were also drawn to his calls for justice. While most of them seemed to be aware that Reinado was a renegade and had been accused of involvement in a military revolt that led to a number of killings, they seemed impressed with this military toughness. "Yeah, it's true", confirmed Bayu one day when we were sitting in the Borja da Costa Park, "Alfredo is OK. Maybe he did some bad things, but he knows how to be a leader." Bayu and the others had expressed their changing attitudes towards Gusmão. He no longer commanded their adoration. Reinado came to fill this leadership void and they could relate to his mobilising calls for justice and "the truth". Female members of Gembel said they were also attracted to Reinado's "strong man" masculine identity.

Major Alfredo Reinado's discourse on “justice” was an important constituent of the "utopic future" vision that he offered as an alternative to the lost promises of the resistance struggle. While Xanana Gusmao had occupied the role of all encompassing hero during the clandestine

2 Relationships between political parties and youth groups are topics of immense interest and importance, which unfortunately fall beyond the scope of this article.

3 Alfredo Reinado led a rebellion in the military and played a major role in the disintegration of the relation between the police and military, which precipitated the 2006 crisis. After eluding authorities for almost two years, he was killed in gunfire on an attack at Jose Ramos-Horta's residence in February 2008. 
period, a decade after Independence, the glow was beginning to wear off. Many young East Timorese had become disappointed in his inability to not only fulfil promises, such as that everybody would have a job), but there was also waning belief that Gusmao had the right intentions in the way he had included young people in the clandestine movement. Needless to say, the void left by Gusmao as the only hero was filled by Alfredo, but not completely, although he is also represented as a hyper masculine and militarised style of leader that continues to be dominant in Timor-Leste.

After Reinado's death, a Dili-based-Indonesian-language publication wrote a kind of eulogy on its editorial page with the title, "Alfredo - an historical icon". The piece explains, "Alfredo is a difficult youth icon to ignore in Timor... [he also] changed the climate of East Timorese politics... Now he has gone forever but he leaves behind a history [of] fighting discrimination and evil" (Time Timor: 2008).

The "Reinado case", as it became known, highlights cycles of violence that continue in postcolonial Timor and the pain and trauma that remains unaddressed and unacknowledged by the leadership (Niner: 2008). It also says much about the nature of East Timorese youth and the manifestation of a marginalised and militarised youth generation with narrow options in cultural references for constructing their identities as post-independent youth. Given the historical fetish for the military leader type in Timor-Leste, it is not difficult to understand the popular appeal of Major Alfredo Reinado, who for many ordinary East Timorese citizens, came to fill the void of the exemplary resistance leadership figure. The loyalty he elicited from young people was visible in graffiti painted around Dili and the fact that youth gangs signed a pact in support of him.

While both male and female Gembel members harboured adoration for Reinado"s "strong" military style leadership, the cultural references were not limited to this. Their participation in print-making workshops showed their interest in issues of peace and justice and an international connection. This multiple range of activities defies singular understandings of them as "wild youth," as represented by the "conflict paradigm" approach that tends to only view East Timorese as either victims or perpetrators of violence (particularly in the literature after the 2006 crisis - see for example Harrington: 2007; World Bank: 2007).

\section{Experiences of Contingent Agency}

The printmaking workshops (Bexley: 2007, 2009) that involved Gembel youth illustrate the ways in which young East Timorese were able to exercise a degree of agency at the margins. They wished to assert their identity as East Timorese youth who are productive and socially connected members of society, despite their marginality. In 2008, after two successful collaborations in Canberra and Indonesia, the printmaking collective Culture Kitchen that I established with Canberra-based printmakers, Jon Priadi, Julian Laffan and Bernie Slater, decided to hold a training workshop and exhibition in Timor-Leste with the Gembel artists. I secured funding for Culture Kitchen and a member from Taring Padi, ${ }^{4}$ Bayu Widodo, to travel to Timor-Leste for a

4 Taring Padi is a Yogyakarta-based art collective that established itself in the Indonesian art world in 1998 with a call to a return to a more popular orientated arts approach (Ind. seni kerakyatan). For the last ten years, Taring Padi has since worked with communities in rural and urban Java and further abroad in Asia and Australia. They work in 
month-long schedule of workshops and an exhibition. This international environment enabled creation of a space where East Timorese artists could assert their national belonging and claim to the notion of East Timorese youth.

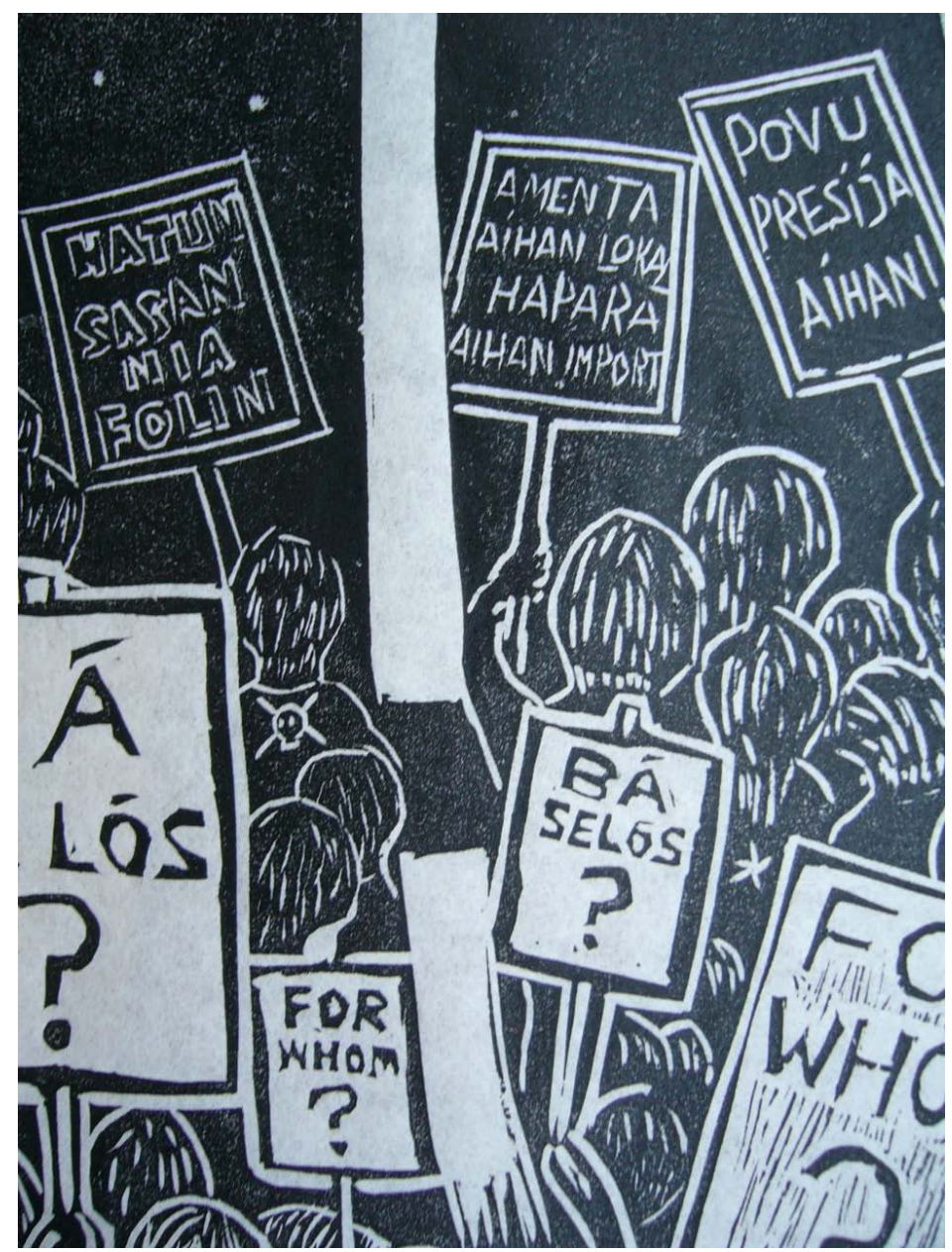

"Povo presija ai han" (The people need food). Photo by the author.

Printmaking is a relatively new art form in Timor-Leste and the power of the communicative possibilities of print definitely struck a chord with Gembel artists. Given the lack of resources available to the members of the group, they had a natural inclination for a do-it-yourself philosophy that requires young East Timorese to think creatively to meet their needs. This way of life provides a firm base for printmaking, which requires manual manipulation of materials using hand-held tools. The bold, graphic nature of relief printing suited the sense of urgency that the Gembel artists had in communicating their concerns. The possibilities of multiplicity and widespread dissemination were also appealing.

During the workshops with Gembel, discourses about justice were discussed and visually represented in a series of lino-prints. While the discourses of justice demonstrate a continuity of concern with older members of the Geracão Foun, the specific topics of justice were different. "Justice" for these young artists relates to equality of power and wealth, rather than the "justice" of Timor-Leste"s struggle for Independence against Indonesian occupation, which encom-

a number of genres of visual culture and are best known for their woodcut prints engaging with social and political issues. This woodcut print style has been taken up by Gembel artists. 
passed the concerns of the older members of Geracão Foun. The lino-prints illustrate young East Timorese' criticism of East Timorese government priorities. The rice shortage, the purchase of luxury four-wheel drive vehicles and the installation of outdoor cinema screens on the government palace building as a token attempt to curb youth violence became key issues of debate and representation in the works.

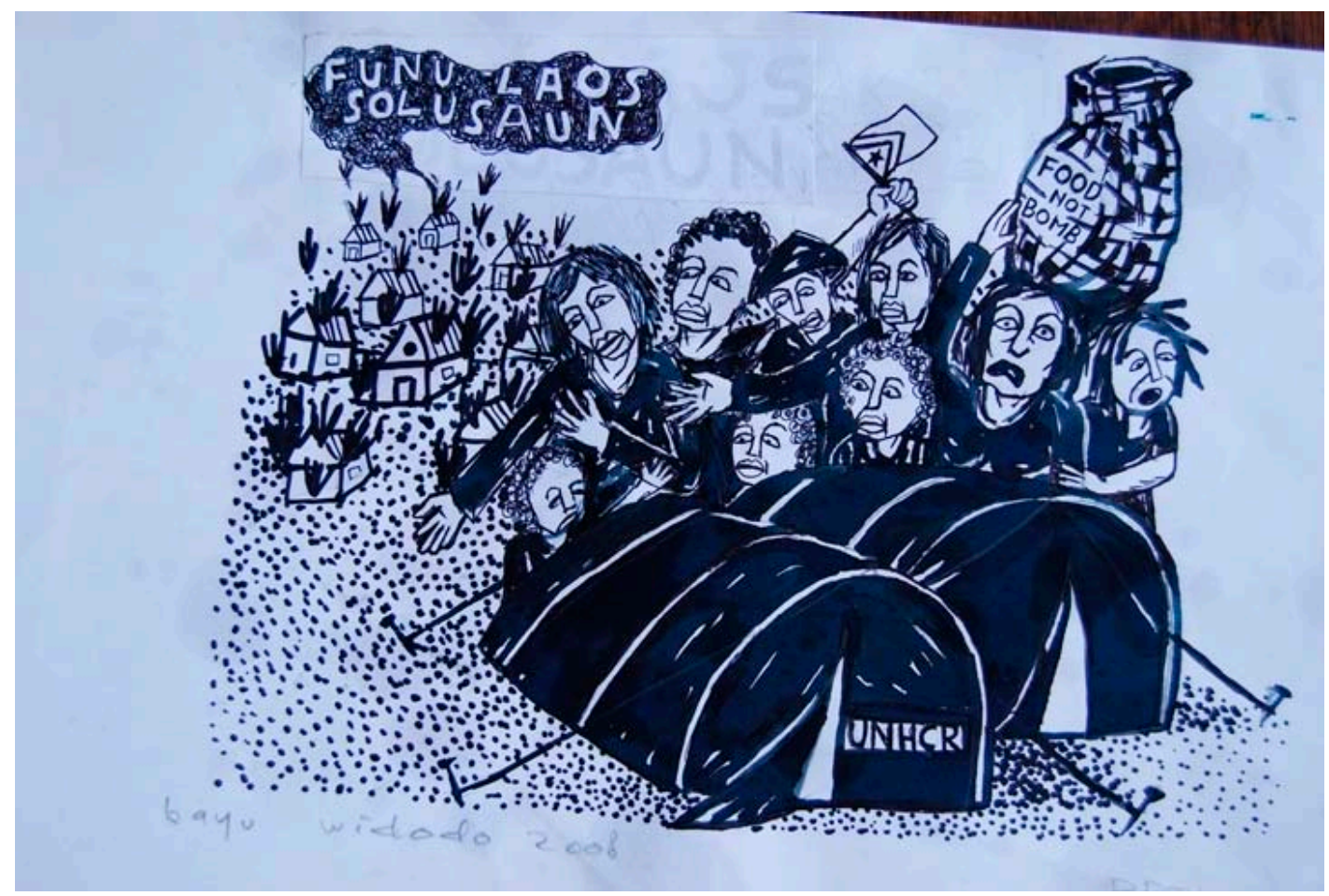

"Funu Laos solusaun"(War is not a solution). Photo by the author.

The works produced by Gembel in collaboration with Culture Kitchen and Taring Padi illustrate the multifaceted nature of youth in contemporary Timor-Leste. They are not easily categorised as violent and disconnected youth but must also be seen for their efforts to forge a place of belonging at the margins. The themes address the ways in which the youth applied indigenous concepts such as ajuda malu (Tet. helping one another). Rather than focusing on conflict, the artworks and the collaborative processes illustrated the ways in which young East Timorese were immensely interconnected citizens, since they related to each other, as youth, as easterners, as westerners and as East Timorese citizens prioritising people-to-people relationships with Australians and Indonesians. The visual representations in the artwork also illustrate how young East Timorese were connected to both "traditional" cultural knowledge and the contemporary "modern" context of the nation-state, and therefore defy the representations of problematic "urban youth groups" (Scambary et al.: 2006). One of the four lino-prints, entitled Tebe-hare, illustrated the traditional dance, the tebe-tebe that portrays rice-crushing in which the dancers step in and out, encircling a mound of harvested rice. This is an important symbol for the East Timorese and it is remarkable that it has been taken up by young Timorese in a new context. Bayu, one of the young Gembel artists explained, "They still use Tebe-hare in my village to turn rice into food. It is also important because it reaffirms our cultural identity of self-sufficiency (Tet. ukun rasik aan)". 


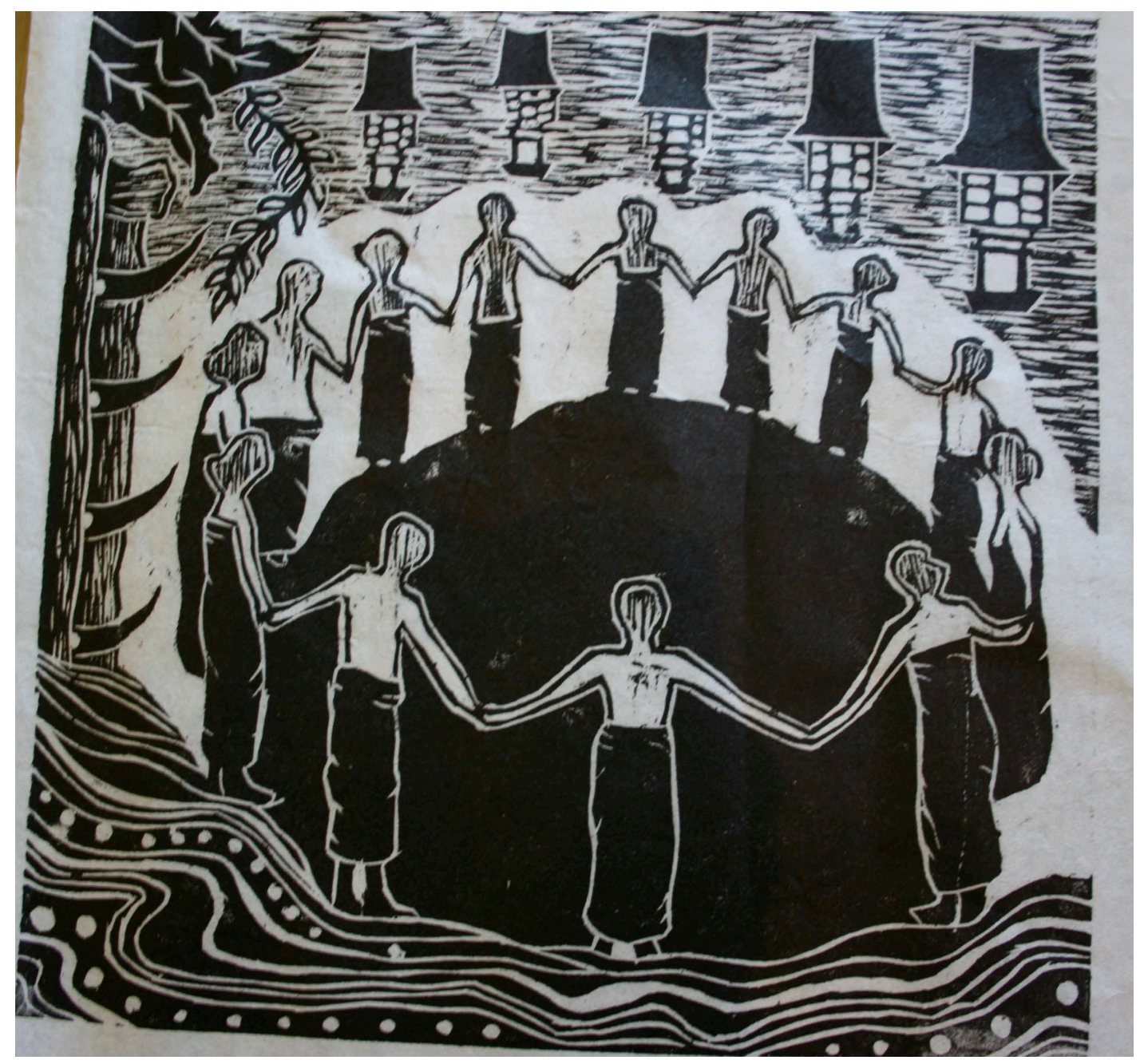

“Tebe-hari” by Bayu, one of the Gembel artists.

The picture Gembel presents is complex in light of Timor-Leste's postcolonial redefinition. This group is representative of a new generation of youth in Timor-Leste who are coming of age in an era radically different from that of the older members of the Geracão Foun and where the new nation-state insists on defining parameters of inclusion and exclusion. The case study of Gembel illustrates the ways in which power relations become replayed in the post-colony. The older members of the Geracão Foun redefined the borders of belonging by excluding Gembel members from activities because they were perceived to be ignorant and involved in the "wrong type" of demonstration activity. Although their membership to Geracão Foun was constantly being challenged, Gembel continued to draw on past cultural references in their attempts to exercise a degree of agency in their marginalised existence. However, this is a circumscribed agency. Gembel's representations of themselves defy being represented as violent and urbanbound youth as portrayed by the conflict paradigm. The ways in which they were able to represent themselves become possible within the context of an international art project, outside of the "traditional" and "local" power structures that marginalises them. 


\section{Conclusion}

The 2006 socio-political crisis was symptomatic of the profound (and ongoing) sociopolitical transformations Timor-Leste experienced as a postcolonial new nation-state. As described by others (Bexley: 2009; Bovensiepen: 2014), the postcolonial state has provided opportunities for new forms of inclusion and exclusion to emerge, which brings new meaning to the "resilience" of not only enduring traditional forms of community, rituals and practice, but also of power relations. The ways in which young people were marginalised during the clandestine movement continued after Independence. The socio-political crisis of 2006 was an effect of the nation-state's preoccupation with defining belonging. By its very nature, the nation-state must define inclusion and exclusion. Power dynamics and relations between young and old marked by difference that were established during the clandestine movement (have been repeated. Younger East Timorese were marginalised and excluded from staking a claim in both the official discourses of belonging and from alternative notions of cultural citizenship that relied on temporal and contingent notions of the suffering, patriotic youth. The new youth generation in Timor-Leste does not share the same history of the resistance movement as the Geracão Foun. However, in an era of uncertainty surrounding cultural citizenship and belonging, they exercise their available agency by drawing upon historical and gendered cultural references of the youth generations that have gone before them and by engaging with ideas, people and projects beyond the borders of their nation-state, even while the power relations established during the clandestine resistance continue to be resilient well into Independence.

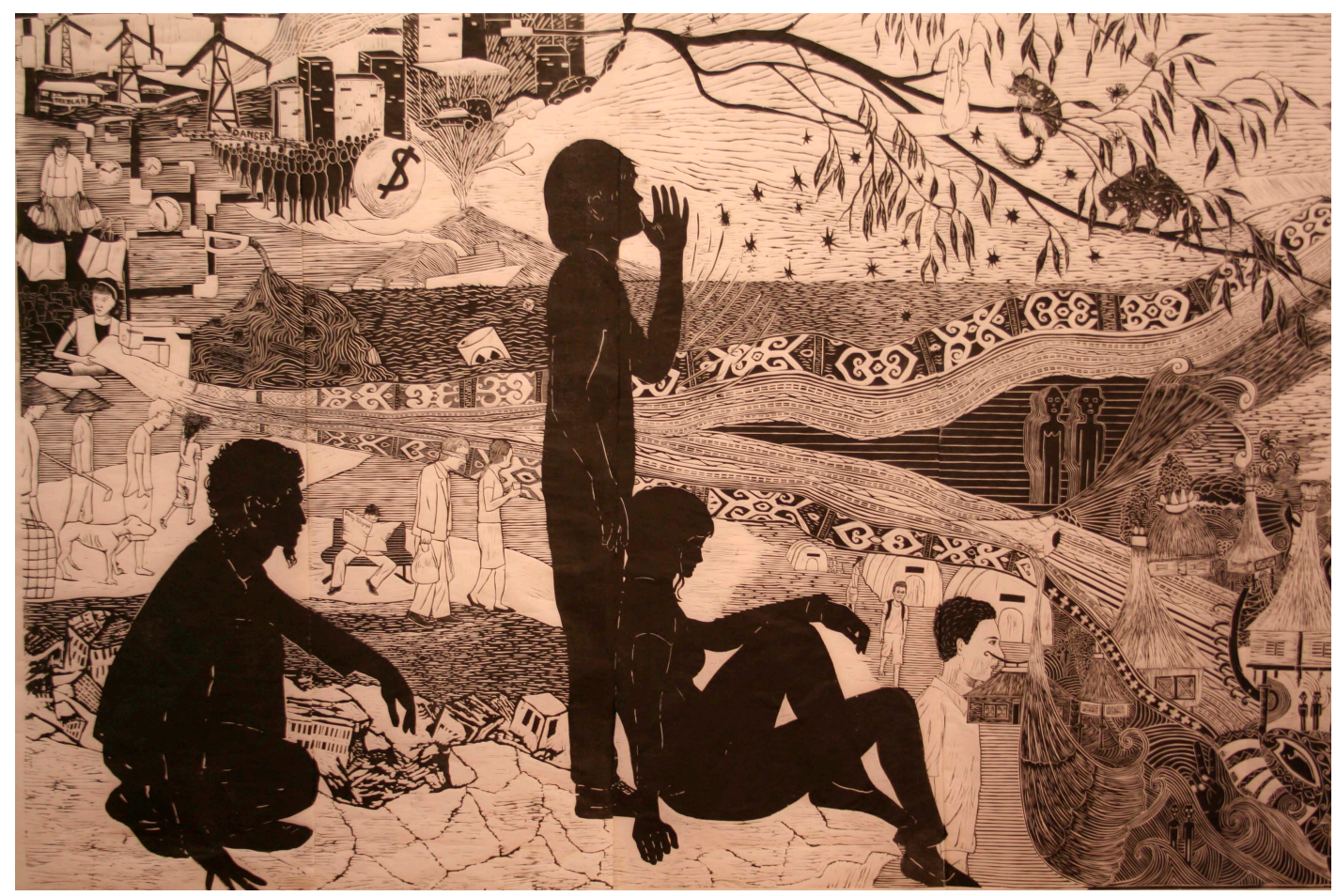

"Recovering Lives Across Borders”The Culture Kitchen 3 X 3m lino cut on paper exhibition in Dili, Timor-Leste as part of the workshop. 


\section{BiblographY}

Bexley, A. 2007. We refuse to become victims. Indonesian, Australians and Timor Leste artists collaborate. Inside Indonesia, 90. Retrieved 10 October, 2007, from http://www.insideindonesia.org/content/view/604/47/.

Bexley, A. 2009. Youth at the crossroads. The politics of identity and belonging in Timor-Leste. Unpublished PhD thesis, Australian National University, Canberra.

Bexley, A. \& N. Rodrigues-Tchailoro. 2013. Consuming Youth: East Timorese in the resistance against Indonesian occupation. The Asia Pacific Journal of Anthropology Special Issue: Engaging Processes of Sense-Making and Negotiation in Contemporary Timor-Leste. 14 (5).pp. 405-422.

Bexley, A. \& M. Nygaard-Christensen. 2014. The Lost Leadership of Timor-Leste. New Mandala. Available: http://asiapacific.anu.edu.au/newmandala/2014/11/07/the-lostleadership-of-timor-leste/

Bovensiepen, J. 2014. Installing the insider "outside": house reconstruction and the transformation of binary ideologies in independent Timor-Leste. American Ethnologist. Vol 41. 2. 290-304.

Bourdieu, P. 1977. Outline of a Theory of Practice. Cambridge. Cambridge University Press.

Harrington, A. 2007. 25th of May 2006 Crisis and War Crimes in Timor Leste. East Timor Law Journal. Retrieved 03 June, 2007, from http://www.eastimorlawjournal.org/ ARTICLES/2007/WarCrimesinTimorAndrewHarrington.pdf/.

Niner, S. 2008. Major Alfredo Alves Reinado: cycles of torture, pain, violence. Australia Policy Forum. 18 February. Revised 14 March. Retrieved 15 March, 2008, from http:/www. globalcollab.org/Nautilus/australia/apsnet/policy

Nygaard-Christensen, M. 2012. The Rebel and the Diplomat: Revolutionary Spirits, Sacred Legitimation, and Democracy in Timor-Leste. Pp. 209-229 in: Bubandt, N. and van Beek, M. (Eds). Varieties of Secularism in Asia: Anthropological Explorations of Religion, Politics, and Spirits. Routledge. London: Routledge.

Scambary, J., Gama Da, H., \& \& Barreto, J. 2006. A Survey of Gangs and Youth Groups in Dili, East Timor: Report commissioned by AusAID.

Scott, J. 1985. Weapons of the Weak: everyday forms of peasant resistance. Yale University Press, Yale.

Time Timor. 2008. Alfredo-an historical icon. Timor Timor: Dili, Timor-Leste. pp 2.

World Bank. 2007. Timor-Leste's Youth in Crisis: Situational Analysis and Policy Options. Report prepared for the World Bank. 